\title{
LEGAL STATUS OF THE PROSECUTOR \\ IN THE COMMERCIAL PROCEEDINGS OF UKRAINE \\ AND PRACTICE OF EUROPEAN COURT \\ OF HUMAN RIGHTS
}

Hryhorchuk M. V.

\section{INTRODUCTION}

Our logical and comparative analysis of the current commercial procedural legislation of Ukraine showed that the statutory limits of involvement of the prosecutor in the consideration and resolution of cases by commercial courts provide a rather ambiguous picture, which requires a deep theoretical and practical evaluation. We are convinced that all the elements that form the legal image of the prosecutor as a participant in the trial should be unified namely through the legal specification.

In the previously published articles, we have defined the concept of a legal specification meaning a set of powers delegated by the state to a statutory party of regulatory processes, and which contains essential features that distinguish it from other equivalents of its regulators ${ }^{1}$.

Therefore, in this part of the study it is proposed to focus attention on the essential specification of the prosecutor, both the entity and the parties to the commercial proceedings. While making theoretical and legal generalizations on these issues, we take into account the procedural equality of the parties, as specified in part 1 of Article 46 (Procedural rights and obligations of the Parties) of the Commercial Procedural Code of Ukraine (hereinafter referred to as the CPC) ${ }^{2}$.

\section{Legal basis and theoretical and legal substantiation of the status of the prosecutor in accordance with the Commercial Procedural Code of Ukraine and other legislative acts}

According to the Law of Ukraine "On the Prosecutor's Office", the Prosecutor's Office of Ukraine performs the functions formalized by the Constitution of Ukraine to protect human rights and freedoms, the general

\footnotetext{
1 Григорчук М.В. Правова характеристика як оціночна категорія у підходах до розуміння процесуального статусу суб'єктів захисту прав учасників господарських відносин. Право і суспільство. 2019. № 5. С. 18-23.

2 Господарський процесуальний кодекс України : Закон України від 06 листопада 1991 р. № 1798-XII / Верховна Рада України. URL: http://zakon5.rada.gov.ua/laws/show/1798-12 (дата звернення: 08.02.2020).
} 
interests of society and the state. The functions of the prosecutor's office in accordance with the provisions of Article 2 are as follows:

1) state prosecution in court;

2) representing the interests of a citizen or a state in court in cases determined by this Law;

3) supervising the observance of the law by the bodies conducting the law enforcement intelligence-gathering activities, inquiry, pre-trial investigation;

4) overseeing compliance of laws in the enforcement of criminal judgments, as well as in the application of other coercive measures related to the restriction of personal freedom of citizens.

Considering the abovementioned, namely the separation of powers of the prosecutor as a participant in the process, it is advisable to make some clarifications that, in our opinion, will have a significant impact on the further formation and content of the prosecutor's legal specification in the commercial proceedings.

Thus, being de jure in the same regulatory conditions, the parties to the commercial proceedings come to it with significantly unbalanced substantive procedural positions, in which the public status of the prosecutor far outweighs the scarves of legal scales on the side of the participant of the process he represents. Therefore, it is very difficult for the court to ensure compliance with the provisions of Article 15 of the CPC on the conduct of proceedings in accordance with the principle of proportionality, taking into account: the task of commercial litigation; ensuring a reasonable balance between private and public interests.

The analyzed scientific materials and the regulatory framework inspire the belief that the prosecutor's independence, as defined by Article 16 (Guarantees of the prosecutor's independence) of the Law of Ukraine "On the Prosecutor's Office", should be attributed to the legal specification of the prosecutor as a subject of protection of the rights and interests of economic entities, and according to which the independence of the prosecutor is ensured, inter alia:

- the procedure for exercising powers determined by procedural and other laws;

- prohibition of unlawful influence, pressure or interference with the exercise of the prosecutor's powers.

Part 2 of this Article states that, in the exercise of functions of the prosecution office, the prosecutor is independent from any unlawful 
influence, pressure, interference and is guided in his/her activity only by the Constitution and laws of Ukraine ${ }^{3}$.

One of the factors that are intended to assert the authority of the public prosecutor in the society is the imposition of a duty on public authorities, local self-government bodies, other state bodies, their officers and officials, as well as individuals and legal entities and their association to respect the independence of the public prosecutor and refrain from exercising any form of influence over the prosecutor in order to impede the performance of official duties or to make an unlawful decision. The limits of reasonable criticism of the prosecutor's activities are determined in the light of the European Convention on Human Rights and the case law of the European Court of Human Rights (part 5 of the Article 16) ${ }^{4}$.

Next. We consider that the basic elements of the legal specification of the prosecutor as a subject of protection of the rights and the interests protected by law of participants of commercial relations are the normative registration of his rights and obligations (Article 19), as well as the liability (Article 20) under the Law of Ukraine "On the Prosecutor's Office".

Thus, in accordance with the provisions of Article 20 of the Law, damage caused by unlawful decisions, actions or omissions of a prosecutor shall be compensated by the state irrespective of its fault in the manner prescribed by law. The state is entitled to a right of recourse to the public prosecutor in the event that the damage caused by the public prosecutor to the state expense will be reimbursed in the amount of compensation paid in the event of the establishment of a criminal offense by the prosecutor on the court's conviction against him, which entered into force.

Thus, by delegating to a prosecutor a certain amount of authority and providing guarantees to ensure the necessary conditions for the fulfillment of the tasks assigned to the prosecutor's office, the Law provides for compensators, who are intended to protect the participants of commercial relations from abuse by employees of the prosecutor's office.

In our opinion, a separate and extremely important element of the prosecutor's legal specification is the obligation to adhere strictly to the oath of the prosecutor, for the breach of which the statutory liability is established. This requirement is contained in Part 3 of this Article.

\footnotetext{
3 Про прокуратуру : Закон України від 14 жовтня 2014 р. № 1697-VII. / Верховна Рада України. URL: https://zakon.rada.gov.ua/laws/card/1697-18 (дата звернення 08.02.2020).

4 Конвенція про захист прав людини і основоположних свобод. Рада Європи. Ратифікація, підстава 475/97-BP. URL: https://zakon.rada.gov.ua/laws/card/995_004 (дата звернення: 08.02.2020).
} 
According to the requirements of paragraph 4 of Article 20, the prosecutor is obliged, among other things, to act only on the basis, within the limits and in the manner provided by the Constitution and laws of Ukraine.

Considering the substantive procedural grounds for the prosecutor's participation in the commercial proceedings, it should be noted the following. Pursuant to Article 23 (Representation of the interests of a citizen or a state in court) of the Law, representation by the public prosecutor of the interests of a citizen or a state in court consists in carrying out procedural and other actions aimed at protecting the interests of a citizen or a state, in cases and in the manner prescribed by law.

Part 4 of the said article requires prosecutors to justify in court the grounds for representation, and the representation of the interests of a citizen or a state in court is carried out only after the court has confirmed the grounds for representation.

Part 5 of Article 55 of the CPC (Procedural rights of authorities and persons who the law entitles with the right to appeal in the interest of other persons) provides that the refusal of the authority empowered to exercise the relevant functions in the disputed legal relationship from the claim filed by the prosecutor in the interests of the state (statements), filing by him the application to leave the lawsuit without consideration does not deprive the prosecutor of the right to sustain a claim (statement) and to demand the consideration of the case on the merits, but according to part 6 - the prosecutor, in order to resolve the issue of the existence of grounds for review of court decisions in a case, considered without his (her) participation, has the right to read the case files in court and receive their copies.

However, it should be noted that the procedural commercial legislation as amended on 15.12.2017 (Law of Ukraine "On Amendments to the Commercial Procedural Code of Ukraine, Civil Procedure Code of Ukraine, Code of Administrative Judiciary of Ukraine and other legislative acts" significantly reduced the scope of powers of prosecutors in court proceedings. Such a conclusion follows from a comparative analysis of the provisions of Articles 53, 55 of this Code and Article 29 in its previous version.

The table we have drawn up clearly shows the significant removal of prosecutors as participants in commercial proceedings and the deprivation of their number of objective opportunities while representing the interests of entities (see table 1). 
Table 1

\begin{tabular}{|c|c|}
\hline $\begin{array}{r}\text { Commercial Proce } \\
\text { of Ukraine (las } \\
\mathbf{1 5 . 1 2 . 2 0}\end{array}$ & $\begin{array}{r}\text { Commercial Proc } \\
\text { of Ukraine (las } \\
15.12 .20\end{array}$ \\
\hline 1 & 2 \\
\hline $\begin{array}{l}\text { Article } 53 \text { (Par } \\
\text { judicial process of b } \\
\text { who the law entitl }\end{array}$ & $\begin{array}{r}\text { Arti } \\
\text { case re }\end{array}$ \\
\hline $\begin{array}{l}\text { Part } 3 \text { - in the cases specified by } \\
\text { law, the prosecutor goes to court with } \\
\text { a statement of claim, participates in the } \\
\text { consideration of cases on his claims, } \\
\text { and can also enter on his own initiative } \\
\text { in a case in which the proceedings } \\
\text { are opened on the claim of another } \\
\text { person, before the trial of the merits, } \\
\text { files an appeal, cassation complaint, } \\
\text { a statement on the review of a court } \\
\text { decision on newly discovered or } \\
\text { exceptional circumstances. } \\
\text { Part } 4 \text { - a prosecutor who appeals to } \\
\text { a court in the interests of the state, in a } \\
\text { claim or other statement of complaint, } \\
\text { substantiates the violation of the } \\
\text { interests of the state, the need for their } \\
\text { protection, the grounds for appeal } \\
\text { to the court prosecutor, determined } \\
\text { by law, and also specifies the body } \\
\text { authorized by the state to perform the } \\
\text { relevant functions in controversial } \\
\text { relationship. Failure to comply with } \\
\text { these requirements results from } \\
\text { the application of the provisions of } \\
\text { Article 174 of this Code (Leaving a } \\
\text { motion with no progress, returning a } \\
\text { statement of claim - Part } 4 \text { (there are } \\
\text { no grounds for bringing a prosecutor } \\
\text { to court in the interests of the State or } \\
\text { for bringing to court a person entitled } \\
\text { with the right to go to court in the } \\
\text { interests of another person). }\end{array}$ & $\begin{array}{l}\text { The prosecutor participates in the } \\
\text { consideration of cases on his claims, and } \\
\text { can also take on his own initiative in a case } \\
\text { initiated by the claim of other persons, at any } \\
\text { stage of its consideration for the representation } \\
\text { of interests of the citizen or the state. } \\
\text { In order to enter the case, the } \\
\text { prosecutor may file an appeal, cassation } \\
\text { appeal, application for review of the } \\
\text { decision by the Supreme Court of } \\
\text { Ukraine, review the decision in newly } \\
\text { discovered circumstances, or inform } \\
\text { the court and take part in the hearing of } \\
\text { the case initiated by the claim of other } \\
\text { persons. In this case, in order to represent } \\
\text { the interests of a citizen or a state in a } \\
\text { commercial court (regardless of the form } \\
\text { in which the representation is made), } \\
\text { the prosecutor must justify the existence } \\
\text { of the grounds for such representation } \\
\text { provided for by the second or third } \\
\text { section of Article } 25 \text { of the Law of } \\
\text { Ukraine "On the Prosecutor's Office". In } \\
\text { order to represent the interests of a citizen } \\
\text { in a commercial court, the prosecutor } \\
\text { must also provide documents confirming } \\
\text { not attainment of majority, incapacity or } \\
\text { limited capacity of the respective citizen, } \\
\text { and the written consent of the legal } \\
\text { representative or body to whom the law } \\
\text { has the right to protected rights, freedoms } \\
\text { and interests of the respective person } \\
\text { Failure of a prosecutor to comply with the. }\end{array}$ \\
\hline
\end{tabular}

5 Господарський процесуальний кодекс України : Закон України від 06 листопада 1991p. № 1798-XII / Верховна Рада України. URL: https://zakon.rada.gov.ua/laws/show/1798-12/ ed20170803 (дата звернення: 08.02.2020). 


\begin{tabular}{|c|c|}
\hline 1 & 2 \\
\hline $\begin{array}{l}\text { Article 55. Procedural rights of } \\
\text { bodies and persons who the law } \\
\text { entitles with the right to appeal in the } \\
\text { interest of other persons. } \\
\text { Part } 5 \text { - the refusal of the body } \\
\text { authorized to perform the relevant } \\
\text { functions in the disputed legal } \\
\text { relations from the claim (statement) } \\
\text { made by the prosecutor in the interest } \\
\text { of the state, the submission of the } \\
\text { statement of dismissal without review } \\
\text { does not deprive the prosecutor of the } \\
\text { right to support the claim (statement) } \\
\text { and to request a hearing on the merits. } \\
\text { Part } 6 \text { - the prosecutor and other } \\
\text { person who the law entitles with the } \\
\text { right to appeal in the interest of other } \\
\text { persons in order to decide whether } \\
\text { there are grounds for reviewing court } \\
\text { decisions in a case heard without his } \\
\text { (her) participation, has the right to } \\
\text { read and receive the case file in court } \\
\text { copies. The prosecutor uses the same } \\
\text { right in order to decide whether to } \\
\text { enter the case on the claim (statement) } \\
\text { of another person. }\end{array}$ & $\begin{array}{l}\text { requirements for granting a commercial } \\
\text { court substantiation of the grounds for } \\
\text { representing the interests of a citizen or a } \\
\text { state in an economic court shall result in } \\
\text { the return of his/her petition (statement, } \\
\text { complaint) in accordance with the procedure } \\
\text { established by Article } 63 \text { of this Code. } \\
\text { If the commercial court accepts the claim } \\
\text { filed by the prosecutor in the interests of the } \\
\text { state in the person of the body authorized } \\
\text { to perform the functions of the state in } \\
\text { the disputed legal relations, the said body } \\
\text { acquires the status of the plaintiff. In } \\
\text { case of the adoption by the commercial } \\
\text { court of the claim filed by the prosecutor } \\
\text { in the interests of the state, stating the } \\
\text { absence of the authority empowered to } \\
\text { perform the functions of the state in the } \\
\text { disputed legal relations, or the lack of } \\
\text { such authority to apply to the commercial } \\
\text { court, the prosecutor acquires the status of } \\
\text { the plaintiff. In order to resolve the issue } \\
\text { of the grounds for initiating the review } \\
\text { of court decisions in a case, considered } \\
\text { without the participation of the prosecutor, } \\
\text { the prosecutor has the right to familiarize } \\
\text { himself with the case file in court, to } \\
\text { make extracts from it, to receive copies of } \\
\text { documents in the case files. } \\
\text { In order to be involved in a case that } \\
\text { has already been initiated, the prosecutor } \\
\text { submits to the commercial court an } \\
\text { appropriate application. } \\
\text { The prosecutor involved in the case is } \\
\text { by the prosecutor in the interests of the } \\
\text { state does not deprive the prosecutor of } \\
\text { resolution of the dispute in substance. } \\
\text { party, except for the right to conclude a } \\
\text { settlement agreement. } \\
\text { The refusal of the prosecutor to file a } \\
\text { claim does not deprive the plaintiff of the } \\
\text { right to seek a resolution of the dispute on } \\
\text { the merits. }\end{array}$ \\
\hline
\end{tabular}


Pursuant to the provisions of paragraph 3 of Article 53 of the Commercial Procedural Code, the prosecutor may, in the cases specified by law, intervene on his own initiative in a case initiated in another person's case before the merits of the case are commenced.

Among other restrictions, including depriving a prosecutor of the right to enter a case at any stage of its consideration, the most unjustified, in our opinion, is the refusal to represent the interests of a citizen in the Commercial Court.

Removing from the current version of Article 53 of the Commercial Procedural Code a citizen as a participant in the process in whose interests the prosecutor had the right to intervene, in our opinion, the legislator significantly reduced the degree of legal protection of citizens who can apply to the commercial court for the renewal of their violated subjective law or protected the law of interest as a person who has suffered losses from the results of independent commercial activity.

We have no reason to believe that the phrase "other person's interests" is sufficient in terms of the embedded volume of the legal content to extend its effect to "citizen" as a hypothetical participant in the process. Assuming such a judgment, the further content of the analyzed articles completely leads the individual out of the field of procedural commercial consideration. The conclusion from this situation is that the citizen in the commercial process is forced to defend his violated right alone, enlisting only the help of a lawyer.

In assessing the degree of efficiency and timeliness of the prosecutor's performance of the functions of protection in the commercial court of the interests of the commercial entity or citizen, it should be noted that the legislator provides an opportunity for the prosecutor to become involved in resolving the commercial dispute at an early stage. The prosecutor is obliged to inform the citizen and his/her legal representative or the respective subject of authority beforehand before going to court. If the court confirms the existence of grounds for representation, the prosecutor shall exercise the procedural powers of the respective party to the proceedings.

At the same time, a prosecutor in a commercial nature case is not entitled to participate unconditionally in such a process only by his personal decision. The legislator has introduced certain instruments of restraint on such independent actions of the prosecutor, namely that the grounds for representation may be challenged by the citizen or his legal representative or the subject of power.

According to the provisions of paragraph 6, Article 23 of the Law of Ukraine "On the Prosecutor's Office", in the course of the representation 
of the interests of a citizen or a state in court, the prosecutor shall have the right, in the manner provided by the procedural law and the law governing enforcement proceedings, to: 1) apply to court with a claim (statement, submission); 2) act in case brought by the claim (statement, submission) by any other person at any stage of the proceedings; 3 ) initiate the review of court decisions, including in the case of another person's statement; 4) to participate in the hearing of the case; 5) to file a civil suit during criminal proceedings in the cases and order specified by the criminal procedural law; 6) participate in enforcement proceedings in the execution of decisions in a case in which the prosecutor represented the interests of the citizen or the state in court; 7) with the permission of the court to familiarize with the materials of the case in court and the materials of the enforcement proceedings, to make extracts from them, to receive free copies of the documents contained in the files of the case or the enforcement proceedings.

As shown by our theoretical and legal analysis of the normative substantiation of the prosecutor's legitimate participation in the judicial review of cases of economic nature, the separate provisions of Article 23 of the Law of Ukraine "On the Prosecutor's Office" do not fully correspond with the procedural rights determined by the $\mathrm{CPC}$, and in some cases contradict them.

Article 24 of the Law of Ukraine "On the Prosecutor's Office" introduced the peculiarities of the implementation of certain forms of representation of interests of a citizen or a state in court, according to which the right to file a claim (application, filing) in the civil, administrative, commercial court procedure is granted to the Procurator General, his first deputy and his deputy, heads of regional and local prosecutor's offices, their first deputies and deputies (part 1).

The right to file an appeal or cassation appeal against a judgment in a civil, administrative or commercial case shall be granted to the prosecutor who participated in the trial, as well as regardless of the participation in the hearing of the higher-level prosecutor: the Procurator General, his first deputy and deputies, and heads local prosecutors, first deputies and deputy heads of regional prosecutors' offices (part 3).

The right to file a statement for review of a judgment in newly discovered circumstances, a petition for review of a judgment by the Supreme Court of Ukraine in a civil, administrative, commercial case shall be vested in the Procurator General, his first deputy and deputies, heads of regional prosecutor's offices (part 4) of the commented article. 
Considering the abovementioned, as well as taking into account the provisions of Article 29 of the CPC (last updated 15.12.2017), it is appropriate to note some positive elements that the legislator eliminated clearly inappropriate to the economic process of action. Thus, in determining the legal specification of the prosecutor as a participant in the commercial process, it was revealed incorrect reference to the powers of the prosecutor, contained in Article 29 of the Commercial Procedural Code of Ukraine.

For example, this article made reference to the fact that a prosecutor, in order to represent the interests of a citizen or a state in an economic court (regardless of the form in which the representation is made), must substantiate the existence of grounds for such representation provided for in paragraphs 2 or 3 of Article 25 of the Law of Ukraine "On the Prosecutor's Office". In this case, such a reference was incorrect, since the said article defined the prosecutor's powers to supervise the observance of the law by the bodies conducting investigative activities, inquiries, pre-trial investigation, and there was no part of the third one.

It should be noted that certain provisions of the Law of Ukraine "On the Prosecutor's Office" have not been brought into conformity with the current legislation.

In particular, Article 24 states there are rights of certain prosecutors to file an application for review of a court decision in newly discovered circumstances, an application for review of a court decision to the Supreme Court of Ukraine. However, the current legislation, namely Article 17 (Judicial System) of the Law of Ukraine "On Judicial system and status of judges" provides that the highest court in the judicial system is the Supreme Court (Part 2).

\section{Generalized scientific approaches, opinion of the Constitutional Court of Ukraine and the ECHR in understanding the status of prosecutors in commercial litigation}

The generalization of our theoretical and practical framework on the issues raised gives us grounds to conclude that the legal bases of the prosecutor's entry into the commercial process can be conditionally divided into subjective and objective. In the first category, in our opinion, we should include the possibility of participation in commercial processes, when the prosecutor personally sees the legitimate grounds for such representation. The deterrent element in preventing a prosecutor from illegally using his powers as a party to a commercial dispute is the possibility of bringing 
him to the statutory liability and the court's assessment of the lawfulness of entering into a commercial case.

In the second category, we include the right of the prosecutor to file lawsuits concerning the interests of the state or other persons and is not dependent on the will of the prosecutor. They can be considered, for example, filing a petition for review of the case in the newly discovered circumstances, as well as representing the interests of the state as a clearly formed imperative component among other functions of the prosecutor's office.

An analysis of scientific intelligence and case law on the issue indicated that science and practice had not fully found consensus in approaches to understanding the prosecutor's procedural status. In this view, the normative framing of this issue is ruled by the decision of the Constitutional Court of Ukraine in the case on the constitutional submission of the Supreme Arbitration Court of Ukraine and the Prosecutor General's Office of Ukraine on the official interpretation of the provisions of Article 2 of the Arbitration Procedure Code of Ukraine (case on representation of the State Prosecutor's Office in the Arbitration Court). The Constitutional Court of Ukraine notes that the provisions of the fourth part of the first article of Article 2 of the Arbitration Procedure Code of Ukraine in the context of paragraph 2 of Article 121 of the Constitution of Ukraine should be understood so that prosecutors and their deputies submit claims to the arbitration court in the interests of the state and not in the interests of enterprises, institutions and organizations regardless of their subordination and ownership.

Under the representation of the Prosecutor's Office of Ukraine the interests of the state in the arbitral tribunal within the meaning of paragraph 2 of Article 121, of the Constitution of Ukraine, and Articles 2 and 29 of the Arbitration Procedure Code of Ukraine, it is necessary to understand protection of the interests of the state.

These actions include the filing of a statement of claim by the prosecutor, his participation in the trial of the statement of claim, as well as in the consideration of the court of any other case on the initiative of the prosecutor or by the court, if necessary to protect the interests of the state.

The Constitutional Court of Ukraine also clarifies that the "interests of the state" is an appraisal concept, the prosecutor or his deputy in each case independently determines with reference to the law under which the claim is made, in what exactly the violation of material or other interests occurred of the State, substantiates in the statement of claim the need for 
their protection and designates a body authorized by the state to perform the respective functions in the disputed relations ${ }^{6}$.

The above provision in the decision of the Constitutional Court of Ukraine is fully consistent with the current state of commercial procedural legislation, which has undergone significant changes for two decades. This implies that approaches to understanding the procedural status of the prosecutor in the commercial process of representing the state have remained unchanged.

The analyzed array of information about the scientific work on this issue distinguishes several basic directions, according to which the prosecutor's office of Ukraine represents the interests of the state in court as one of the types of representation in court, which differs from other types of representation by a number of specific features. To them, scientists include: the composition of representatives and the range of subjects whose interests they represent, the scope of powers, forms of their implementation.

Proponents of the first line, among whom there are O. Zadniprovskyi ${ }^{7}$ and $\mathrm{S}$. Fursa ${ }^{8}$ consider representation by the prosecutor of interests in court as a procedural representation in the case of inherent features, which is little different from classical procedural representation.

This vision of the problem raised is supported by T. Dunas ${ }^{9}, \mathrm{M} . \mathrm{Mychko}^{10}$ and V. Valiukh ${ }^{11}$.

While analyzing the above legal positions, let us express our views on this issue. We consider that those scholars who disagree with such a statement of the problem and, as arguments, point out the difference between the legal status of a lawyer as a solicitor, a citizen and a prosecutor, that the prosecutor is always a representative of the so-called public authority a very important circumstance. We believe that the subjective defense is always the subjective

\footnotetext{
6 Рішення Конституційного Суду України від 8 квітня 1999 р. Офіційний вісник України. 1999. № 15. Ст. 614.

7 Задніпровський О. Права прокурора у світлі нової Конституції України. Право Украӥни. 1997. № 1. С. 72-73, 110.

8 Фурса С. Теоретичні аспекти правового та процесуального становища прокурора в цивільному судочинстві. Право Украӥни. 1998. № 12. С. 68-70.

9 Дунас Т.О., Руденко М.В. Прокурор в цивільному процесі України: Сутність, завдання, повноваження : навчальний і науково-практичний посібник / за наук. ред. М.В. Руденка. Харків, 2006. 340 с.

10 Мичко М.I. Функції та організаційний устрій прокуратури. Донецьк : Донеччина, 2001. $272 \mathrm{c}$.

11 Валюх В. Актуальні проблеми представництва прокурором інтересів громадянина або держави у господарському суді. Підприємнищтво, господарство і право. 2002. № 4. С. 92-96.
} 
right of the individual in the broadest interpretation of the matter, since only subjective interest is at the root of any dispute, including business.

Representatives of another concept consider representation of interests by the prosecutor in court as a special subaspect of representation by law. One of the arguments that some supporters of this concept substantiate their vision for is the position of the Supreme Court of Ukraine, is set out in the Resolution of March 2, 2010 in Case № 21-2368во09. This document states that a prosecutor in administrative proceedings carries out a legal representation, the peculiarity of which is that the legal representative independently (without a power of attorney), on the basis of the law, carries out the procedural rights and obligations of the party or third person, which he represents, acting in its interests, which, however, do not affect the general rules of representation. Defending their scientific position, representatives of such a direction entitles the prosecutor with procedural rights of the party in the process.

I.V. Zabolotska notes that the main arguments of the proponents of this view are that the prosecutor who filed the claim or brought the case is, above all, the subject of evidence, who possesses the same procedural rights as the subjects of the disputed legal relationship, as well as links to correctly identify the subject of the dispute and prove your legal position ${ }^{12}$.

We consider that the prosecutor who has entered into the commercial process acquires an unconditional status of a party to the dispute, that is, it is fully covered by the provisions of Article 42 (Rights and Obligations of the parties to the case) and 46 (Procedural Rights and Obligations of the Parties) of the CPC.

According to M.M. Stefanchuk, adoption of the Law of Ukraine "On the Prosecutor's Office" (2014) and amending the procedural legislation substantially reform the mechanism of implementation by the Prosecutor's Office of Ukraine of the function of representing the interests of the citizen or the state in court, which necessitates additional studies of general methodological issues of legal status the act of exercising the function of representing the interests of a citizen or state in court ${ }^{13}$.

At the same time, our study will not be complete enough without highlighting the practice of international human rights institutions, first of all, the European Court of Human Rights (hereinafter referred

12 Заболоцкая И.В. Доказательная деятельность прокурора. Закон и право. 2000. № 1. C. 29-30.

13 Стефанчук М.М. Напрями вдосконалення процесуального статусу прокурора як суб'єкта реалізації функції представництва інтересів громадянина або держави в суді. Науковий вісник Ужгородського начіонального університету. 2015. № 2. С. 115-121. 
to as ECHR), in the chosen approaches to assessing the involvement of the prosecutor in the judicial process which are the sources of law for Ukraine, which is explicitly set out in Article 17 of Law № 3477-IV and Part 4 of Article 10 of the CPC of Ukraine, shows that the ECHR's position regarding the evaluation of the prosecutor's participation in the trial is filled with a number of reservations. This is evidenced by our logical and legal analysis of the ECHR Judgment of 15.01.2009 in the case Menchinskaya v. Russia (Application № 42454/02) where the court indicated such circumstances:

30. The Court reiterates that the principle of equality of arms is one element of the broader concept of fair trial, within the meaning of Article 6 paragraph 1 of the Convention. It requires "a fair balance between the parties": each party must be given a reasonable opportunity to present his case under conditions that do not place him at a substantial disadvantage vis-à-vis his opponent...

32. The Court reiterates that since a prosecutor or comparable officer, in recommending that an appeal on points of law should be allowed or dismissed and thereby became the ally or opponent of the parties, his participation is likely to create a feeling of inequality to a party ${ }^{14}$.

It follows from the foregoing that the main objection to the role of the public prosecutor in the judicial process is the hypothetical threat to the equality of the parties, since such a situation may lead to a narrowing of the concept of a fair trial within the meaning of paragraph 1 of Article 6 of the Convention. The position expressed by the ECHR is brought about by the creation of a substantial inconvenience for it (the party on which the prosecutor acts or the fact of the prosecutor's involvement as a party) compared to the other party.

\section{CONCLUSIONS}

We are convinced that the situational assessment of the provisions cited as an example of the ECHR's decision cannot fully and objectively attest to the procedural status of the prosecutor in the commercial process, since it is a general understanding of the state representative's own involvement in the trial. If such a position seems to be acceptable for the civil process, then a properly authorized person should be involved for the representation of the state in the judicial process in order to defend and protect the state interests.

\footnotetext{
14 «Менчинська проти Російської Федерації» (Menchinskaya v. Russia) (скарга № 42454/02). URL: http:file://C:/Users/User/Downloads/001-90620.pdf. (дата звернення: 09.02.2020).
} 
We also believe that the principles of justice set out in the Constitution of Ukraine and the relevant provisions of the procedural codes of Ukraine guarantee that the parties have a fair legal equilibrium in the judicial process. The basis for such a conclusion is the norms, for example, of the Commercial Procedural Code of Ukraine, in particular, Article 86 (Evaluation of evidence), according to which the court evaluates the evidence on its own belief, based on a comprehensive, complete, objective and direct examination of available in the case evidence (part 1).

Pursuant to paragraph 2 of this article, no evidence has a pre-established force for the court. The Court assesses the appropriateness, admissibility, credibility of each evidence individually, as well as the sufficiency and correlation of the evidence in its totality [CPC].

Such a conclusion is fully justified given that the title and position of the parties do not matter to the court. The court evaluates the evidence provided by the case participants in accordance with the law.

At the same time, the current legislation requires substantial rethinking and reformatting of the ways of scientific search through the established constitutional order in the approaches to the role and status of the prosecutor in the economic process. Thus, in accordance with the provisions of paragraph 3 of Part 1 of Article 131-1 of the Constitution of Ukraine, the Prosecutor's Office carries representation of the interests of the state in the court of exceptional cases and in the manner specified by law [Constitution].

The key elements in approaches to the theoretical and practical elaboration of this problem, in our opinion, are the notions of "exceptional cases" and "the order established by law". These concepts are those normatively defined limits of professional "intervention", which contain a correct essential understanding of the problem raised.

The article deals with the peculiarities of the procedural status of the prosecutor in the commercial proceedings. Based on the results of the theoretical and legal analysis of the legislation in force in Ukraine, as well as taking into account individual decisions of the European Court of Human Rights, the elements of the prosecutor's legal specification are identified. The author's definition of the concept of "legal specification" is provided.

The application of certain general scientific special methods (comparative, historical, abstraction methods, method of logical approach, etc.) made it possible to carry out author's research of legal processes, which are indispensable to a deep theoretical and legal understanding of the instruments of realization of the subjective right to defense. 
Conducted theoretical and legal generalization of scientific views and jurisprudence on the grounds for involving the prosecutor in the litigation allowed to distinguish a number of factors that cause wellfounded discussions among the representatives of science and participants in the trial. Attention is drawn to the reservations made in the separate judgments of the European Court of Human Rights regarding the maximum limitation of the involvement of a prosecutor in litigation.

Considering the results of the logical and legal analysis of the statutory instruments that regulate the activity of the court in the broadest sense, we provide a number of opposing generally accepted scientific and legal position of the facts regarding the alleged excessive legal pressure in the presence of the prosecutor, as well as the hypothetical pressure on the court. We argue that Ukraine is a rule of law in which the constitutional guarantees of the independence of the court are duly provided, first of all, that no evidence has a pre-established force for the court (Part 2 of Article 89 of the Civil Procedure Code, Part 2 of Article 86 of the Commercial Procedural Code, part 2 of Article 90 of Code of Administrative Judicial Procedure of Ukraine). If we accept the assumption of the role of the prosecutor in the judicial process as a factor of inequality, we must admit that the independence of the judge and the subordination of the rule of law to the court cannot be discussed.

\section{SUMMARY}

Choosing by Ukraine a European model of development leads to a profound and comprehensive transformation of the whole system of Ukrainian lawmaking and law enforcement. Thus, there is a growing practical and scientific interest to legal institutions that are assigned by law with the role of state-enforced coercive instruments to protect the rights and interests of legal entities involved, including economic entities.

The notion of the prosecutor's exceptional importance in litigation, obtained as a legacy from the Soviet regime, significantly discredits this institution, and places it in a position counter to the generally accepted notion of service to the people and the state. All of the abovementioned stipulates the necessity of concentrating the efforts of the law-making bodies on the path of full legal integration and adaptation of the prosecutor's office to the needs of the society, as well as the affirmation of its role as an impartial participant in solving conflicts of different branches of law.

Based on the published scientific work, monitoring of the legislation and practice of the European Court of Human Rights, a theoretical and legal analysis of the procedural status of a prosecutor in a commercial court as well 
as the legal characterization of this participant in the trial have been made. The table comparing the current and previous versions of the Commercial Procedural Code of Ukraine clearly demonstrates a significant narrowing of the procedural rights of the prosecutor in the commercial process that definitely prevents one of the basic constitutional tasks - to represent the interests of the state in court.

\section{REFERENCES}

1. Григорчук М.В. Правова характеристика як оціночна категорія у підходах до розуміння процесуального статусу суб'єктів захисту прав учасників господарських відносин. Право i суспільство. № 5. 2019. C. $18-23$.

2. Господарський процесуальний кодекс України: Закон України від 06 листопада 1991 р. № 1798-XII / Верховна Рада України. URL: http://zakon5.rada.gov.ua/laws/show/1798-12 (дата звернення: 08.02.2020).

3. Про прокуратуру: Закон України від 14 жовтня 2014 p. № 1697-VII / Верховна Рада України. URL: https://zakon.rada.gov.ua/laws/ card/1697-18 (дата звернення: 08.02.2020).

4. Конвенція про захист прав людини і основоположних свобод. Рада Свропи. Ратифікація, підстава 475/97-BP. URL: https://zakon.rada.gov.ua/ laws/ card/995_004 (дата звернення 08.02.2020).

5. Про внесення змін до Господарського процесуального кодексу України, Цивільного процесуального кодексу України, Кодексу адміністративного судочинства України та інших законодавчих акті : Закон України від 03 жовтня 2017 р. № 2147-VIII.URL : https://zakon.rada. gov.ua/ laws/show/2147-19 (дата звернення: 08.02.2020).

6. Господарський процесуальний кодекс України: Закон України від 06 листопада 1991p. № 1798-XII / Верховна Рада України. URL: https://zakon.rada.gov.ua/laws/show/1798-12/ed20170803 (дата звернення: 08.02.2020).

7. Про судоустрій і статус суддів : Закон України від 07 липня 2010 р. № 2354-VI / Верховна Рада України. URL: https://zakon.rada.gov.ua/laws/ card/2453-17 (дата звернення: 08.02.2020).

8. Рішення Конституційного Суду України від 8 квітня 1999 p. Офіиійний вісник України. 1999. № 15. Ст. 614.

9. Задніпровський О. Права прокурора у світлі нової Конституції України. Право України. 1997. № 1. С. 72-73, 110.

10. Фурса С. Теоретичні аспекти правового та процесуального становища прокурора в цивільному судочинстві. Право Украӥни. 1998. № 12. C. $68-70$. 
11. Дунас Т.О., Руденко М.В. Прокурор в цивільному процесі України: Сутність, завдання, повноваження: навчальний і науково-практичний посібник / за наук. ред. М.В. Руденка. Харків, 2006. 340 с.

12. Мичко М.I. Функції та організаційний устрій прокуратури. Донецьк : Донеччина, 2001. - 272 с.

13. Валюх В. Актуальні проблеми представництва прокурором інтересів громадянина або держави у господарському суді. Підприємництво, господарство і право. 2002. № 4. С. 92-96.

14. Постанова Верховного Суду України від 2 березня 2010 р. у справі № 21-2368. URL: https: www.reyestr.court.gov.ua (дата звернення: 09.02.2020).

15. Заболоцкая И.В. Доказательная деятельность прокурора. Закон и право. 2000. № 1. С. 29-30.

16. Стефанчук М.М. Напрями вдосконалення процесуального статусу прокурора як суб'єкта реалізації функції представництва інтересів громадянина або держави в суді. Науковий вісник Ужгородського національного університету. 2015. № 2. С. 115-121.

17. «Менчинська проти Російської Федерації» (Menchinskaya v. Russia) (скарга № 42454/02). URL: http:file:///C:/Users/User/ Downloads/001-90620.pdf. (дата звернення: 09.02.2020).

Information about author: Hryhorchuk M. V., Candidate of Law Sciences, Associate Professor of the Department of Public Law Disciplines "KROK" University 30 - 32, Tabyrna str., Kiev, Ukraine

DOI https://doi.org/10.30525/978-9934-588-43-3/1.30 